\title{
Influence of rootstock on the productive behaviour of 'Orange Red' apricot under Mediterranean conditions
}

\author{
José EgeA*, David RuIz, Pedro MARTínez-Gómez
}

Departamento de Mejora y Patología Vegetal, CEBAS-CSIC, PO Box 164, 30100 Espinardo, Murcia, Spain agr007@cebas.csic.es jegea@cebas.csic.es
${ }^{*}$ Correspondence and reprints

Received 19 January 2004 Accepted 23 April 2004

Fruits, 2004, vol. 59, p. 367-373 (C) 2004 Cirad/EDP Sciences All rights reserved

DOI: $10.1051 /$ fruits:2004035

RESUMEN ESPAÑOL, p. 373

\section{Influence of rootstock on the productive behaviour of 'Orange Red' apricot under Mediterranean conditions.}

Abstract - Introduction. 'Orange Red' is an apricot cultivar released in the United States and characterised by large fruit of very good quality for both the fresh market and processing. For this reason, this cultivar is greatly appreciated in Europe, especially in France. However, its production is erratic under Mediterranean climate conditions. Materials and methods. The influence of two rootstocks ('Manicot' apricot and 'GF31' Myrobolan plum) on the productive behaviour of 'Orange Red' was studied under Mediterranean conditions in Murcia (Southeast Spain). Results and discussion. 'Orange Red' grafted onto 'GF31' Myrobolan flowered slightly later than those grafted onto 'Manicot' apricot. However, differences in the date of ripening of fruits were small. On the other hand, the percentage of flower bud retention and levels of floral fertility were higher when 'Orange Red' was grafted onto 'GF31' than onto 'Manicot', resulting in higher yields and fruits with a smaller weight. The increase in flower bud retention of 'Orange Red' grafted onto the rootstock 'GF31' was the main factor responsible for the increase in yield observed with this rootstock. Conclusion. Interaction between the cultivar and rootstock is presented as an interesting strategy for cultivar adaptation to different climatic areas.

Spain / Prunus armeniaca / climatic factors / rootstocks / graft compatibility / flowers / fruit / yields

Influence du porte-greffe sur la production de l'abricotier 'Orange Red' en climat méditerranéen.

Résumé - Introduction. 'Orange Red' est un cultivar d'abricotier venu des États-Unis et caractérisé par un grand fruit de très bonne qualité aussi bien pour le marché de produits frais que de conserve. Pour cette raison, le cultivar est très apprécié en Europe et tout particulièrement en France. Cependant, sa production est erratique en climat méditerranéen. Matériel et méthodes. L'influence de deux porte-greffes (abricotier 'Manicot' et prunier Myrobolan 'GF31') sur la production du cultivar 'Orange Red' a été étudiée dans les conditions méditerranéennes de Murcia (sud-est de l'Espagne). Résultats et discussion. Greffé sur le Myrobolan 'GF31', 'Orange Red' a fleuri légèrement plus tard que greffé sur 'Manicot'. Cependant, les différences entre dates de maturation des fruits ont été réduites. D'autre part, les taux de nouaison et les niveaux de fertilité florale ont été plus élevés sur 'Orange Red' greffé sur 'GF31' que sur ce même cultivar greffé sur 'Manicot', ce qui a entraîné de plus hauts rendements et des fruits de plus petits calibres. L'augmentation du taux de nouaison de 'Orange Red' greffé sur le portegreffe 'GF31' a été le principal facteur responsable de l'amélioration de rendement observé avec ce porte-greffe. Conclusion. L'interaction entre le cultivar et le porte-greffe serait une stratégie intéressante pour l'adaptation d'un cultivar à différents environnements climatiques.

Espagne / Prunus armeniaca / facteur climatique / porte greffe / compatibilité de greffe / fleur / fruit / rendement 


\section{Introduction}

'Orange Red ${ }^{\circledR}$ (synonymous with Barth ${ }^{\circledR}$ ) is the denomination of an apricot cultivar released in New Jersey, United States, and encoded initially as 'NJA-32' [1]. This new release resulted from the cross between the Iranian cultivar 'Lasgerdi Mashhad' and 'NJA2', another new selection released in New Jersey from the open pollination of the cultivar Morden 604 [2].

In general, irregularity of yield is one of the main handicaps in temperate fruit production [3] and has been shown to be due to different problems concerning climatic adaptation and flower development [4-8] On the other hand, the rootstock has been described as a factor affecting the chill requirements of cultivars in different climatic conditions [9-11].

The objective of this work was to study the influence of the rootstock on the productive behaviour of the apricot cultivar 'Orange Red' under Mediterranean climatic conditions.

\section{Materials and methods}

\subsection{Plant material}

Four replications of the apricot cultivar 'Orange Red' were grafted onto two different rootstocks (four trees per rootstock): seedlings of 'Manicot' apricot (a selection of INRA of Avignon, France), and clonal rootstocks of 'GF31' Myrobolan plum (a selec-

Table I.

Accumulation of chill units for 'Orange Red' apricot trees studied in an experimental field (Murcia, Spain) from November 1st to February 15th according to the model of Richardson et al. [21].

Year Chill units accumulated

$\begin{array}{cc}1997-1998 & 960 \\ 1998-1999 & 1339 \\ 1999-2000 & 1350 \\ 2000-2001 & 1147 \\ 2001-2002 & 1523 \\ 2002-2003 & 1354\end{array}$

tion of INRA of Bordeaux, France). Two repetitions of the French apricot cultivar 'Bergeron' grafted onto 'Manicot' rootstock (two trees in total) were also assayed as reference in some experiments.

\subsection{Experimental field}

The experiments were conducted in an experimental orchard in Calasparra, in the region of Murcia, Southeast Spain (lat. $37^{\circ} \mathrm{N}$, long. $\left.1^{\circ} \mathrm{W}\right)$. The experimental field, with sandy soil without waterlogging problems, was situated at $450 \mathrm{~m}$ altitude and $50 \mathrm{~km}$ from the Mediterranean coast. The trees, spaced $(8 \times$ 8) $\mathrm{m}$, were planted in 1993 . The study lasted 7 years (1996 to 2002). The presence of honey bees guaranteed the adequate pollination of cultivars.

Chill units were calculated according to the model of Richardson et al. [12] and accumulated from (1000 to 1500) units from November 1st to February 15th (table I). According to Guerriero et al. [13], the chill unit requirements of 'Orange Red' are around 1400 units while those of Bergeron are around 1220 units. The chill units in our experimental field were at the limit of the requirements of the apricot cultivars studied and could have affected their productive behaviour.

\subsection{Date of flowering and ripening}

The date of flowering was considered to be when $50 \%$ of the flowers of the tree were open (stage F of Fleckinger), observed by an expert. The date of ripening was considered to be the time of the commercial harvest of the fruits by visual observation. These parameters were evaluated for 'Orange Red' and 'Bergeron'.

\subsection{Flower quality: flower bud retention, aborted pistils and floral fertility}

Approximately 500 flower buds were studied on three different branches per tree, randomly chosen for each treatment during the 7 years of the study. The flower bud retention percentage was determined by comparing the initial number of flower buds 


\begin{tabular}{|c|c|c|c|c|c|c|c|c|}
\hline \multicolumn{9}{|c|}{$\begin{array}{l}\text { Table II. } \\
\text { Comparison of fl } \\
\text { grafted onto 'Mar } \\
\text { cultivar 'Bergeron } \\
\text { - Flowering dates }\end{array}$} \\
\hline Cultivar & Rootstock & 1996 & 1997 & 1998 & 1999 & 2000 & 2001 & 2002 \\
\hline Orange Red & $\begin{array}{c}\text { Manicot } \\
\text { GF31 }\end{array}$ & $\begin{array}{c}31 \text { March } \\
-\end{array}$ & $\begin{array}{c}9 \text { March } \\
-\end{array}$ & $\begin{array}{l}20 \text { March } \\
16 \text { March }\end{array}$ & $\begin{array}{l}15 \text { March } \\
24 \text { March }\end{array}$ & $\begin{array}{l}12 \text { March } \\
22 \text { March }\end{array}$ & $\begin{array}{l}12 \text { March } \\
15 \text { March }\end{array}$ & $\begin{array}{l}8 \text { March } \\
8 \text { March }\end{array}$ \\
\hline Bergeron & Manicot & 30 March & 6 March & 18 March & 12 March & 10 March & 10 March & 8 March \\
\hline \multicolumn{9}{|c|}{ - Ripening dates } \\
\hline Cultivar & Rootstock & 1996 & 1997 & 1998 & 1999 & 2000 & 2001 & 2002 \\
\hline \multirow[t]{2}{*}{ Orange Red } & Manicot & - & 26 May & 27 May & 25 May & 21 May & 26 May & 30 May \\
\hline & GF31 & - & 26 May & 2 June & 29 May & 21 May & 26 May & 30 May \\
\hline Bergeron & Manicot & - & - & 20 June & 15 June & 19 June & 12 June & 12 June \\
\hline
\end{tabular}

(stage A) and the final number of open flowers (stage F); it is complementary to the flower bud abscission. In addition, the percentage of aborted pistils (necrosis of pistils) was studied in approximately 500 more flowers, from three other branches per tree, randomly chosen. Finally, another 500 open flowers (stage F) from another three branches per tree were hand-pollinated. The floral fertility percentage was calculated from the number of mature fruits at harvest time divided by the number of flowers pollinated [14]. Flowers were hand-pollinated with compatible pollen from 'Bergeron'.

\subsection{Yield and fruit size}

Yields (kg per tree) were evaluated in the four studied replications of 'Orange Red' grafted onto 'Manicot' and 'GF31' rootstocks. In addition, 10 fruits of each tree were randomly chosen for the evaluation of fruit size (g) in each treatment.

\subsection{Statistical analysis}

The trial was arranged in a completely randomised design. Mean values of flower bud retention, aborted pistils and floral fertility were expressed as percentages, whilst yield was expressed as $\mathrm{kg}$ per tree and fruit weight. A chi-squared $\left(\chi^{2}\right)$ test was used to identify significant differences between the means of the different parameters. Mean values were compared only between the two rootstocks assayed during each year of the study [15].

\section{Results and discussion}

\subsection{Dates of flowering and ripening}

Comparing the times for flowering and ripening of 'Orange Red' and 'Bergeron' grafted onto 'Manicot' and 'GF31' rootstocks, the flowering date in the cultivar 'Orange Red' varied greatly during the different years studied and ranged from March 8th to March 31st (table II). In our experimental conditions, in Murcia, this cultivar blooms around the second week of March, with a flowering date similar to the cultivar 'Bergeron'.

The rootstock seems to have an influence on the time of flowering of 'Orange Red' under our Mediterranean conditions. Trees of 'Orange Red' grafted onto 'GF31' Myrobolan had delayed flowering in comparison with those grafted onto 'Manicot' apricot. This delay was around 10 days in some years. These results agree with those obtained by Chandler [16], Young and Olcott-Reid [11] and Couvillon et al. [9], who found an influence of the rootstock on the flowering date 
Table III.

Productive behaviour of the apricot cultivar 'Orange Red' grafted onto 'Manicot' apricot and 'GF31' Myrobolan plum rootstocks (Murcia, Spain).

\begin{tabular}{|c|c|c|c|c|c|c|c|}
\hline Rootstock & 1996 & 1997 & 1998 & 1999 & 2000 & 2001 & 2002 \\
\hline \multicolumn{8}{|c|}{ Flower bud retention (\%) } \\
\hline Manicot & $15.9 \mathrm{a}$ & $5.3 b$ & $3.5 b$ & $21.3 \mathrm{a}$ & $1.7 \mathrm{a}$ & $43.4 \mathrm{a}$ & $12.2 \mathrm{a}$ \\
\hline GF31 & $16.7 \mathrm{a}$ & $18.6 \mathrm{a}$ & $15.2 \mathrm{a}$ & $34.5 \mathrm{a}$ & $1.5 \mathrm{a}$ & $48.7 \mathrm{a}$ & $19.9 \mathrm{a}$ \\
\hline \multicolumn{8}{|c|}{ Aborted pistils (\%) } \\
\hline Manicot & $49.2 \mathrm{a}$ & - & - & $5.1 \mathrm{a}$ & - & $54.0 \mathrm{a}$ & $12.3 \mathrm{a}$ \\
\hline GF31 & $48.0 \mathrm{a}$ & - & - & $5.0 \mathrm{a}$ & - & $54.0 \mathrm{a}$ & $12.3 \mathrm{a}$ \\
\hline \multicolumn{8}{|c|}{ Floral fertility (\%) } \\
\hline Manicot & - & - & $57.1 \mathrm{a}$ & $12.3 \mathrm{a}$ & - & $57.3 \mathrm{a}$ & $17.8 \mathrm{a}$ \\
\hline GF31 & - & - & $60.3 a$ & $18.7 \mathrm{a}$ & - & $61.4 \mathrm{a}$ & $35.7 \mathrm{a}$ \\
\hline \multicolumn{8}{|c|}{ Yield (kg per tree) } \\
\hline Manicot & - & - & $7.1 \mathrm{~b}$ & $15.3 b$ & $5.6 \mathrm{a}$ & $62.0 \mathrm{a}$ & $15.5 \mathrm{a}$ \\
\hline GF31 & - & - & $45.7 \mathrm{a}$ & $50.3 a$ & $10.8 \mathrm{a}$ & $62.5 \mathrm{a}$ & $20.5 \mathrm{a}$ \\
\hline \multicolumn{8}{|c|}{ Fruit weight (g) } \\
\hline Manicot & - & $99.2 \mathrm{a}$ & $80.2 \mathrm{a}$ & - & $106.2 \mathrm{a}$ & $54.1 \mathrm{a}$ & - \\
\hline GF31 & - & $42.1 \mathrm{~b}$ & $52.6 \mathrm{~b}$ & - & $92.5 \mathrm{a}$ & $53.1 \mathrm{a}$ & - \\
\hline
\end{tabular}

of peach and apple cultivars under low chill conditions.

'Orange Red' sometimes showed an irregular maturation of fruits, different maturation stages of fruits on a tree on the same date, probably due to the lack of adaptation to Mediterranean conditions. This cultivar showed an intermediate maturation in comparison with traditional Spanish apricot cultivars. In our experimental conditions, in Murcia, 'Orange Red' matured at the end of May, around ( 2 to 3 ) weeks earlier than 'Bergeron' (table II). Thus, 'Orange Red' showed a shorter flowering/ripening cycle than 'Bergeron' in our Mediterranean conditions.

The results showed a lesser influence of the rootstock on the ripening date in comparison with its influence on the flowering date. Only in some years was a delay of flowering observed in the trees of 'Orange Red' cultivars grafted onto 'GF31' reflected in the ripening date. Westwood and Chestnut [10] also indicated a lack of influence of the root- stock on the ripening date of pear cultivars, in comparison with the influence observed on the flowering date.

\subsection{Flower quality: flower bud retention, aborted pistils and floral fertility}

Flower bud retention in 'Orange Red' varied greatly during the different years studied, ranging between (1.7 and 43.4)\% with 'Manicot' as rootstock and between (1.5 and $48.7) \%$ in the case of 'GF31' (table III). Such annual variation has also been described in this cultivar by Jay et al. [17], in trial field assays in the south of France. The percentages of flower bud retention (around 15\%) were very low in comparison with the percentages observed on other cultivars [17-19].

With the rootstock 'Manicot', the percentage of flower bud retention was the lowest in most years, although these differences were statistically significant in some of the 
years. However, the differences observed [(14.7 versus 22.2)\% on average, for 'Manicot' and 'GF31', respectively] could be very significant in practice, in terms of final yield, in spite of not being significant in the statistical analysis. 'Orange Red' showed a high flower bud production in our Mediterranean conditions; and a small increase in flower bud retention, as observed with the rootstock 'GF31', could, therefore, greatly increase the profitability of the crop.

The percentage of aborted pistils ranged between 5.0 and 54.0 in both cases, 'Orange Red' grafted onto 'Manicot' or 'GF31' (table III). This annual variation has also been described in 'Orange Red' by Guerriero [20] and Jay et al. [17]. Thus, the results show a lack of influence of the rootstock on the abortion of pistils in apricot flowers. Percentages of aborted pistils of around 5\% (1999) are low in comparison with values observed in other apricot cultivars [17]. However, during the year 2001 these percentages greatly increased, to $54 \%$, probably due to the climatic conditions.

The values of floral fertility in 'Orange Red' ranged between (12.3 and 57.3)\%, using 'Manicot' as rootstock, and between (18.7 and 61.4)\% using 'GF31' (table III). In general, the percentages of floral fertility obtained in our work were low in comparison with percentages observed in other apricot cultivars [14], probably due to the lack of adaptation of 'Orange Red' apricot to Mediterranean climate conditions, as indicated by Beppu et al. [4] for cherry.

Floral fertility for the rootstock 'GF31' showed the highest percentage during all the studied years. These differences were not statistically significant. As for the flower bud retention, the differences observed [(36.1 and $44.1) \%$ on average, in 'Manicot' and 'GF31', respectively] could be very significant in terms of final yield in spite of not being statistically significant. The increase in floral fertility observed with the rootstock 'GF31' could greatly increase the profitability of the crop.

\subsection{Yield and fruit size}

In accordance with the yearly variation observed in the percentages of flower bud retention and floral fertility, yields varied greatly from year to year (table III). Values ranged between (5.6 and 62.0) $\mathrm{kg}$ per tree for 'Manicot', and between (10.8 and 62.5) kg per tree for 'GF31'. This annual variation has been described previously in 'Orange Red' by different authors [17, 20]. The highest cumulative yield was obtained with the rootstock 'GF31'; nevertheless, the differences between the use of the two rootstocks were not statistically significant with the exception of the years 1998 and 1999.

The increase in flower bud retention of 'Orange Red' grafted onto the rootstock 'GF31' was the main factor responsible for the increase in yield observed with this rootstock. For example, during the year 1998, 'Manicot' showed a percentage of flower bud retention of $3.5 \%$ in comparison with the percentage of $15.2 \%$ observed in 'GF31'. These percentages of remaining flowers in the tree were in correlation with the final yield of 'Orange Red', six times higher with 'GF31' (45.7 kg per tree) than with 'Manicot' (7.1 kg per tree).

Fruit weight was affected by the yields obtained in each year with the two rootstocks assayed. Frequently, there was a correspondence between low yield and large fruit weight. Yields varied greatly from year to year and fruit weight ranged between (53.1 and 106.2) g with 'Manicot', and between (42.1 and 92.5) g with 'GF31'. In accordance with the observed yields, fruit weight was the largest with the rootstock 'Manicot' (with the lowest yields) during all the years studied. As for the yields, these differences were not statistically significant with the exception of the years 1998 and 1999.

\section{Conclusions}

According to Chandler [16], rest requirements move across graft unions. In this sense, other flower characteristics could be affected by this interaction between the rootstock and the cultivars, in terms of floral development and fruit set, affecting productive behaviour. Our results show the influence of the rootstock on the productive behaviour of the apricot cultivar 'Orange Red' under the Mediterranean conditions of the study. The rootstock seemed to have an influence on the time of flowering of the cultivar, with a 
smaller influence on the ripening date. On the other hand, the rootstock affected the percentages of flower bud retention and floral fertility with a direct effect on the yield per tree. The increase in flower bud retention observed with the rootstock 'GF31' was the main factor responsible for the increase in yield observed with this rootstock. Our results indicate, then, that the interaction between the cultivar and rootstock could be an interesting strategy for improvement of the adaptation of cultivars to different climatic areas.

\section{Acknowledgements}

This study was financed by the projects Mejora Genética del Albaricoquero (AGF980211-C03-02 and AGL2001-112-C02-01) from the Spanish Ministry of Science and Technology.

\section{References}

[1] Hough L.F., Bailey C.H., 30 years of apricot breeding in New Jersey, Acta Hortic. 121 (1982) 207-210.

[2] Bailey C.H., Cowgill W., Hough L.F., Estimate of chilling requirements of apricot selections, Acta Hortic. 85 (1978) 184-189.

[3] Abbott D.L., Physiology of fruit-set in apple, Pomol. Plant Breed. 7 (1971) 30-32.

[4] Beppu K., Okamoto S., Sugiyama A., Kataoka I., Effects of temperature on flower development and fruit set of "Satohnishiki" sweet cherry (Prunus avium), J. Jpn. Soc. Hortic. Sci. 65 (1997) 707-712.

[5] Browning G., Miller J.M., The association of year to year variation in average yield of pear cv. 'Conference' in England with weather variables, J. Hortic. Sci. 67 (1992) 593-599.

[6] Egea J., Burgos L., Fructification problems in continental apricot cultivars growing under Mediterranean climate. Ovule development at anthesis in two climatic areas, J. Hortic. Sci. Biotech. 73 (1998) 107-110.

[7] Jackson J.E., Hamer P.J.C., The causes of year-to-year variation in the average yield of 'Cox' orange Pippin'apple in England, J. Hortic. Sci. 55 (1980) 149-156.
[8] Rodrigo J., Herrero M., Effects of pre-blossom temperatures on flower development and fruit set in apricot, Sci. Hortic. (Amsterdam) 92 (2002) 125-135.

[9] Couvillon G.A., Finardi N., Magnani M., Freire C., Rootstock influences the chilling requirement of 'Rome Beauty' apple in Brazil, HortScience 19 (2) (1984) 255-256.

[10] Westwood N.M., Chestnut N.E., Rest period chilling requirements of Bartlett pear as related to Pyrus calleryana and $P$. communis rootstocks, Proc. Am. Soc. Hortic. Sci. 84 (1964) 82-87.

[11] Young E., Olcott-Reid B., Siberian C rootstock delays bloom of peach, J. Am. Soc. Hortic. Sci. 104 (2) (1979) 178-181.

[12] Richardson E.A., Seeley S.D., Walker R.D., A model estimating the completion of rest for 'Red Haven' and 'Elberta' peach, HortScience 9 (1974) 331-332.

[13] Guerriero R., Viti R., Monteleone P., Gentili M., La valutazione della dormienza nell' albicocco: tre metodi a confronto, Frutticoltura 3 (2002) 73-77.

[14] Lichou J., Audubert A., Jay M., Costes E., Influence of floral fertility and pollinisation on fruit drop and productivity of apricot, in: Ruhinaz Gülcan, Uygun Aksoy (Eds.), Xth Int. Symp. Apricot Culture, Izmir (Turkey), 1993, ISHS, Leiden, The Nederlands, 1995.

[15] Zar J.H., Biostatistical analysis, Ed. Prentice Hall, New Jersey, USA, 1999, 665 p.

[16] Chandler W.H., Some studies of rest in apple trees, Proc. Am. Soc. Hortic. Sci. 76 (1960) $1-10$.

[17] Jay M., Lichou J., Costes E., Audubert A., Architecture de l'abricotier: évolution de l'arbre et de la mise à fruits, Infos-Ctifl 116 (1995) 28-33.

[18] Legave J.M., García M., Marco F., Some descriptive aspects of drops process of flower buds or young flowers on apricot in south of France, Acta Hortic. 121 (1982) 75-83.

[19] Martínez-Gómez P., Dicenta F., Ruiz D., Egea J., Flower bud abscission in apricot: competition between vegetative and flower buds, and effects of early defoliation and high preblossom temperatures, J. Hortic. Sci. Biotech. 77 (2002) 485-488.

[20] Guerriero R., Albicocco, Frutticoltura 7/8 (1999) 12-16. 


\section{Influencia del patrón en la producción del albaricoquero 'Orange Red' en clima mediterráneo.}

Resumen - Introducción. 'Orange Red' es un cultivar de albaricoquero procedente de EE.UU. y que se caracteriza por un gran fruto de excelente calidad tanto para el consumo fresco como para la conserva. Por esta razón, este cultivar es muy apreciado en Europa y especialmente en Francia. Sin embargo, su producción es irregular en el clima mediterráneo. Material y métodos. Se estudió la influencia de dos portainjertos (albaricoquero 'Manicot' y ciruelo Myrobolan 'GF31') en la producción del cultivar 'Orange Red' en las condiciones mediterráneas de Murcia (sudeste de España). Resultados y discusión. Injertado en el Myrobolan 'GF31', 'Orange Red' floreció ligeramente más tarde que injertado en 'Manicot'. Sin embargo, las diferencias entre las fechas de maduración de los frutos fueron escasas. Por otro lado, el porcentaje de cuajado y los índices de fertilidad floral fueron más altos en 'Orange Red' injertado en 'GF31' que injertado en 'Manicot', lo que engendró un mayor rendimiento y frutos con un calibre menor. El aumento del porcentaje de cuajado de 'Orange Red' injertado en el patrón 'GF31' fue el principal factor responsable de la mejora de rendimiento observada con este patrón. Conclusión. La interacción entre el cultivar y el patrón sería una estrategia interesante para la adaptación de un cultivar a distintos entornos climáticos.

España / Prunus armeniaca / factores climáticos / portainjertos / compatibilidad del injerto / flores / fruto / rendimiento

To access this journal online: www.edpsciences.org 